
likely lipoatrophy

We have been offering subcutaneous micronised depot medroxyprogesterone acetate (Sayana Press) (DMPASC) as an option to women already using the injectable contraceptive, DepoProvera (DMPA-IM) for the last 18 months. To date we have 23 women who are self-administering Sayana Press.

One woman, a healthcare professional used to giving injections and one of our earliest Sayana Press users, reported a significant degree of soreness at the injection site at her annual review in December 2017. She described each site as being acutely tender, even to light touch, for 2-3 days following each injection. This she felt was a negative effect compared with her experience of using DepoProvera, but on balance the benefits of not having to come to clinic for an injection outweighed this drawback at the time and she wished to continue with self-administration of Sayana Press.

She did, however, return to the clinic in February 2018 concerned by two areas of skin dimpling which she recognised as being the sites of two injections (figure 1).

Of note this woman does not have any dermatological or soft tissue conditions, she is fit and well and takes no other medications. She scars and heals normally after minor injuries.

A Yellow Card has been completed and the woman, not overly worried by the visual appearance but not wanting any more dimples, has stopped using Sayana Press. She is considering reverting to DepoProvera.

Skin dimpling is mentioned in the Sayana Press package leaflet under the heading 'Injection site reactions' together with pain, tenderness and lump. Injection site skin reactions were commonly reported in early studies comparing DMPA-SC with DMPA$\mathrm{IM}^{1}$ and are reported in approximately 1 in 10 users $^{23}$ along with many other non-specific side effects such as dizziness, back pain, nausea and tiredness.

Such skin reactions may represent a form of lipoatrophy. Resolution is reported, but it is difficult to give assurance on this matter.

A retrospective, post-marketing analysis of WHO and Swiss spontaneous 


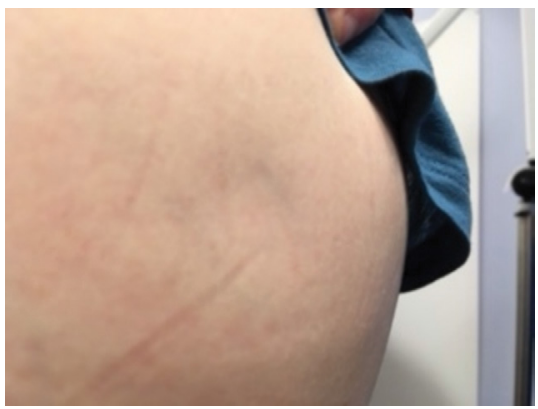

Figure 1 Photograph of anterior abdominal wall showing skin dimpling.

pharmacovigilance reports suggests atrophy may occur several weeks to months after the subcutaneous injection and is potentially persistent. ${ }^{4}$

To date we have not specifically counselled women on the risk of skin dimpling. Consequently we plan to counsel DMPA-SC users to watch for skin dimples which may not become apparent for several months, and report any undue soreness following injections in case this is a factor in the development of skin dimpling.

\section{Jane Bush}

The Centre for Contraception, GU Medicine and HIV Services, North Devon Healthcare Trust, 31 Sidwell St., Exeter EX4 6NN, UK

Correspondence to Dr Jane Bush, The Centre for Contraception, GU Medicine and HIV services, North Devon Healthcare Trust, Exeter EX4 6NN, UK; jane.bush@nhs.net

Contributors There are no other contributors.

Competing interests None declared. Patient consent Obtained.

Provenance and peer review Not commissioned; internally peer reviewed.

(C) Article author(s) (or their employer(s) unless otherwise stated in the text of the article) 2018. All rights reserved. No commercial use is permitted unless otherwise expressly granted.

D Check for updates
BMJ Sex Reprod Health 2018;44:230-231 doi:10.1136/bmjsrh-2018-200120

\section{REFERENCES}

1 Kaunitz AM, Darney PD, Ross D, et al. Subcutaneous DMPA vs. intramuscular DMPA: a 2-year randomized study of contraceptive efficacy and bone mineral density. Contraception 2009;80:7-17.

2 Jain J, Jakimiuk AJ, Bode FR, et al. Contraceptive efficacy and safety of DMPA-SC. Contraception 2004;70: 269-75.

3 Cameron ST, Glasier A, Johnstone A. Pilot study of home self-administration of subcutaneous depo-medroxyprogesterone acetate for contraception. Contraception 2012;85:458-64.

4 Jodiche A, Damke B. Severe injection site reactions after subcutaneous administration of Sayana: a retrospective, post marketing analysis of WHO and Swiss spontenous pharmacovigilancecreports. Swiss Med Wkly 2017;147:w14432. 